\title{
Coiled-Coil-Helix-Coiled-Coil-Helix Domain-Containing Protein 7
}

National Cancer Institute

\section{Source}

National Cancer Institute. Coiled-Coil-Helix-Coiled-Coil-Helix Domain-Containing Protein

7. NCI Thesaurus. Code C97405.

Coiled-coil-helix-coiled-coil-helix domain-containing protein 7 (85 aa, $\sim 10 \mathrm{kDa}$ ) is encoded by the human CHCHD7 gene. This protein may be involved in human height. 